\title{
足関節果部骨折の治療と検討
}

（手術症例について）

$\begin{array}{cccccc}\text { 麻生飯塚病院整形外科 } & & & \\ \text { 森 } & & \text { 英 } & \text { 治・松 隈 } & \text { 雄 弘 } \\ \text { 吉 } & \text { 本 } & \text { 隆 } & \text { 昌・住 } & \text { 吉 和 夫 } \\ \text { 坂 } & \text { 本 } & & \text { 央・案ノ浦 聖 凡 }\end{array}$

\section{Operative Treatment of Fractures of the Ankle}

by

Eiji Mori, Yuuko Matsukuma, Takamasa Yoshimoto, Kazuo Sumiyoshi, Hisashi Sakamoto and Kiyochika Annoura

Dept. of Orthop. Surg., Iizuka Hospital, Iizuka City.

Thirty five cases with uni-, bi-, and tri-malleolar fractures of the ankle were treated by open reduction and internal fixation. Screws were used for most of the fractures. These cases consisted of 29 males and 6 females. The age of the patients ranged from 15 to 74 years and the average age was 42 years. The subjective results were good in 22 cases, fair in 7 cases and poor in 6 cases.

\section{はじめに}

足関節果部骨折は日常しばしば漕遇するととが多い 骨折であり，従来より種々の観血的治療法が考案され ている. 今回我々は昭和 51 年から 59 年 2 月までに当 科において手術治療を施行した 35 症例の 経験を得る ことができたので報告する.

\section{対象および方法}

年令は 15 才から 74 才, 平均 42 才, 男性 29 例, 女 性 6 例, 右側 20 例, 左側 15 例であった.

受傷機転としては, 転倒によるあの 12 例, 野球・ 柔道などのスポーツ外傷によるもの 7 例, 重量物落下 によるもの 7 例，交通事故によるもの 6 例，転落によ るあの 3 例であった.

骨折のタイプは果部骨折の 部位に着目して 分類を 行い，乙れらの骨折に対しては，ほとんど screw を 用いた内固定を行った（表 1). その他の方法として は, plate, K-w， Zuggurtung 法などを用いてい る.
表 1 骨折のタイプと手術方法

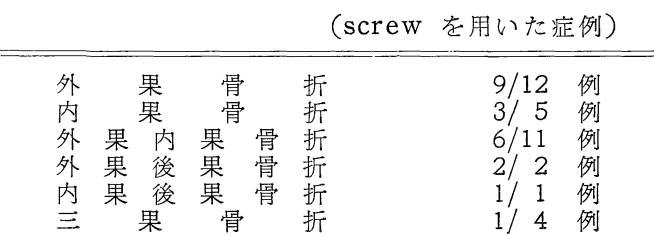

遠位頸腓勒帯結合離開に対しては，wiring 6 例， screw 1 例, tibia bolt 1 例, 放置 2 例の処置を行 い, 三角䩲帯の断裂は特に処置は行わなかった。

結

果

術後整復の確実性を Burwell らのX線所見による 判定基準を用いると， a natomical 30 例 (86\%), fair 2 例 $(6 \%)$, poor 3 例 $(8 \%)$ であった. 術 後 2 ケ月から 4 年 6 ケ月（平均 1 年 1 ケ月）の期間の 症例に，治療成績のアンケート調査を行った（表 2 ）. 更に異なった見地からも調查した（表 3 ）.

代表的な症例を供覧する.

症例 1 ：32 才男性. 転倒にて受傷. 外果内果骨 
表 2 治 療 成 績 (Burwell の基準)

\begin{tabular}{|c|c|c|c|c|c|c|}
\hline & \multicolumn{2}{|c|}{ good } & \multicolumn{2}{|c|}{ fair } & \multicolumn{2}{|c|}{ poor } \\
\hline & sub- & ob- & sub- & ou- & sub- & ob- \\
\hline $\begin{array}{l}\text { uni-malleolar } \\
\text { bi-malleolar } \\
\text { tri-malleolar }\end{array}$ & $\begin{array}{r}11 \\
9 \\
2\end{array}$ & $\begin{array}{r}11 \\
9 \\
1\end{array}$ & $\begin{array}{l}3 \\
3 \\
1\end{array}$ & $\begin{array}{l}3 \\
3 \\
2\end{array}$ & $\begin{array}{l}3 \\
2 \\
1\end{array}$ & $\begin{array}{l}3 \\
2 \\
1\end{array}$ \\
\hline total & $\begin{array}{c}22 \\
(62.9 \%)\end{array}$ & $\begin{array}{c}21 \\
(60.0 \%)\end{array}$ & $\begin{array}{c}7 \\
(20.0 \%)\end{array}$ & $\begin{array}{c}8 \\
(22.9 \%)\end{array}$ & $(17.1 \%)$ & $(17.1 \%)$ \\
\hline
\end{tabular}

表 3 治 㙩 成 績

\begin{tabular}{l|r|c}
\hline & $(+)$ & $(-)$ \\
\hline 足関節運動 痛 & 4 例 (11.4\%) & 31 例 (88.6\%) \\
歩 行時痛 & 12 例(34.3\%) & 23 例 (65.7\%) \\
$\mathrm{ADL}$ 上の支障 & 9 例 $(25.7 \%)$ & 26 例 (74.3\%) \\
$10^{\circ}$ 以上の背屈 & 24 例 (68.6\%) & 11 例 (31.4\%)
\end{tabular}

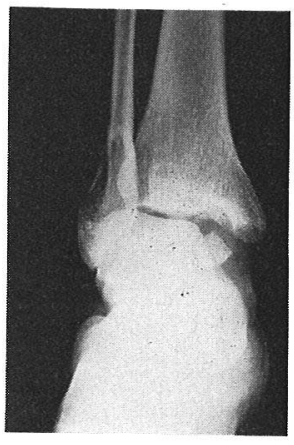

術

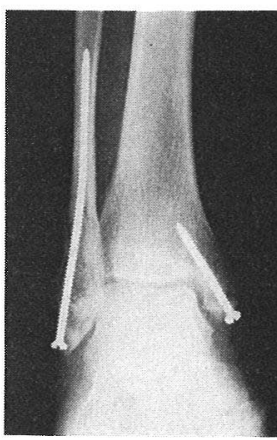

術 直 後

図1 症例 1 外果内果骨折と距骨の外側軽 位. 整復は anatomical である.

折であり，距骨の外側転位がみられた。治療成績は $\operatorname{good}($ 図 1).

症例 $2: 16$ 才男性. 柔道にて受傷. 外果単独骨 折であるが，三角靶帯の 断裂あ疑われ，距骨の外侧

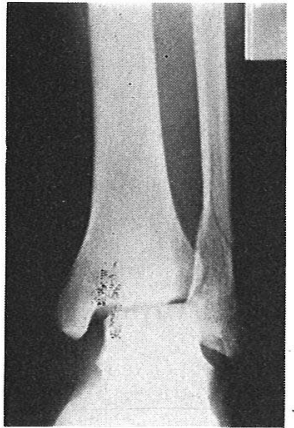

術

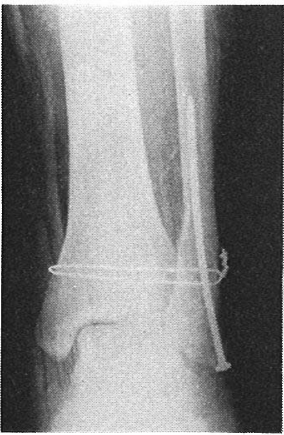

術直後

図 2 症例 2 外果骨折と距骨の外侧転位. 整復は anatomical である。

転位がみられた。遠位脛腓靱带結合離開も疑われ wiring を行った，治療成績は good（図 2).

\section{考察}

足関節は荷重関節として重要な関節であり，その破 綻をきたす果部骨折に対しては，解剖学的整復位とそ の固定が重要である．解剖学的整復位とその固定の為 に強固な内固定を行えば，早期よりの関節運動と荷重 負荷が可能であり， screw による固定は他の方法に おとらずとれを十分に満足するものである. 
治療成績と整復の確実性とは，およそ相関関係を示 すあのであるが, 整復が a natomical なものにも成 績 fair, poor なものがある。

調査症例の整復 a natomical なあのが高値を示す にもかかわらず，成績 good のものが比較的低值を 示したのは，開放骨折で距骨の脱臼を伴った症例や， 患側の踵骨骨折を合併した症例, Sudeck の atrophy を生じた症例など重症例を含み, 条件が悪かった為と 思われる.

遠位脛腓㪄帯結合離開に対しては種々の方法が報告 されているが， $\mathrm{X}$ 線的に離開が著明な場合と, 内外果 の整復内固定を行った後も instability が残存する場 合に，足関節最大背屈位にて wire による整復位保 持を行い，腓骨の生理的運動が行える余裕を残してい る.

三角䩲帯の損傷に対しては，断裂片が関節内に嵌頓 し，整復障害となっている場合には処置を行う心゙きで あるが，それ以外には特に三角䩲帯の修復は試みてお らず，その様な経験もなかった.

$$
\text { ま と め }
$$

足関節果部骨折に対して手術治療を行った症例の治 療成績を述べると共に若干の考察を加えた.

\section{文献}

1) Burwell, H. N.. and Charnley, A. D.: The treatment of displaced fractures at the ankle by ridid internal fixation and early joint movement. J. Bone \& Joint Surg., 47-B : 634-659, 1965.

2) Brodie, I. A. O. D.: The treatment of unstable ankle fractures. J. Bone \& Joint Surg., 56-B : 256-262, 1974.

3) Cedell, C. A.: Supination-outward rotation injuries of the ankle. Acta orthop. scand. Suppl., 110: 1967.
4) Close, J. R.: Some applications of the fanctional anatomy of the ankle joint. J. Bone \& Joint Surg., 38-A : 761-761, 1956.

5) Coonrad, R. W.: Fracture-dislocations of ankle joint with impaction injury of the lateral weightbearing surface of the tibia. J. Bone \& Joint Surg., 52-A: 13371344, 1970.

6）石田義人ほか：足関節果部骨折の分類と治療。 臨整外, 11：1019-1027，1976.

7) Monk, C. J. E.: Injuries of the tibiofibular ligaments. J. Bone 7 Joint Surg., 51-B: 330-337, 1969.

8）野村茂治ほか：陳旧性果部骨折の治療につい て. 臨整外, 10:913-923, 1975.

9）乗松敏晴：果部骨折と足関節脱臼. 整形 - 災害 外科, 12: 1285-1295, 1979.

10）奥村秀雄ほか：足関節踝部骨折の治療．災害医 学, 21: 1243-1258, 1978.

11) Pankovich, A. M.: Fractures of the fibula proximal to the distal tibiofibular syndesmosis. J. Bone \& Joint Surg., 60-A : 221-229, 1978.

12) Ramsey, P. L.: Changes in tibiofibular area of contact caused by lateral talar shift. J. Bone \& Joint Surg., 59-B : 356-357, 1976.

13) Solonen, K. A.: Operative treatment of ankle fractures. Acta orthop. scand., 39: 223-237, 1968.

14) Staples, O. S.: Injuries to the medial ligaments of the ankle. J. Bone \& Joint Surg., 42-A : 1287-1307, 1960.

15）杉浦保夫：足関節脱曰を伴った踝部骨折の治 療. 災害医学, 5: 391-403, 1962.

16）上平用ほか：足関節部骨折について. 臨整 外, 21: 183-193, 1970 .

17) Yablon, I. G.: The key role of the lateral malleolus in displaced fractures of the ankle. J. Bone \& Joint Surg., 59-A: 169-173, 1977. 